This is the accepted version of the article:

Garraio, Júlia (2020), "A priest and the legacies of Portuguese colonialismo", European

Journal of Women's Studies. DOI: 10.1177/1350506820979102

Published version available at:

https://doi.org/10.1177/1350506820979102

\title{
A priest and the legacies of Portuguese colonialism
}

Júlia Garraio

Centre for Social Studies, University of Coimbra

On 11 June 2020 in Lisbon, 4 days after the anti-racism demonstrations that took place in several Portuguese cities following the killing of George Floyd, the statue of the Priest António Vieira (1608-1697) was splattered with red spots and inscribed with the word 'decolonise'. Considering Portugal's prominent role in the transatlantic slave trade, the country's enduring celebration of the 'Discoveries' ${ }^{1}$ and the ever-present urban memorialization of the colonial past, it was to be expected that Portugal would be included among the countries in which there are increasing calls for the removal of symbols associated with colonialism and slavery. However, in a country where statues of key figures of Portuguese colonization, and monuments honouring the veterans of the Colonial War ${ }^{2}$ are so abundant, it may not be obvious why activists focused their attention specifically on someone who, at first sight, appears to be a minor actor in Portuguese colonial projects. The formal inscription on Viera's statue - 'Jesuit, Preacher, Priest, Politician, Diplomat, Defender of the Indians $\underline{\underline{3}}$ and Human Rights, Fighter Against the Inquisition' - though containing inaccuracies, hints at the complexity of the priest's life, namely the dimensions that make him such a controversial figure.

The statue became a target of criticism largely because it dates from 2017, a time when anti-racist activism was becoming more visible in denouncing daily racism and police violence, when new historical perspectives on colonization and scholarship on the politics of memory were gaining visibility in the media and when the brand 'African Lisbon' was enthusiastically embraced by the blossoming tourism industry. The meanings ascribed to the statue were perceived by its critics as expressing a confluence of anachronism, lack of social sensitivity and persistence in ignoring the perspectives of the colonized on 
colonialism. Inspired by a famous 18th-century engraving, the statue depicts Viera as a missionary who holds a cross in a gesture suggesting the brave protection of three naked Amerindian children,,$\underline{4}$ thus emblematically reproducing colonial tropes, which reaffirm the subalternity and 'helplessness' of the colonized and the 'goodness' of the missionary project. $\underline{5}$ That's how, precisely through this 2017 statue, Vieira became the focus of larger contestations over memory that are ongoing in Portugal, and which juxtapose two contemporary narratives about colonial legacies: on one hand, a decolonization narrative, which denounces the persistence of colonial thinking in mainstream Portuguese politics of memory and society's unwillingness to address racism; on the other, a (to a large extent) nationalist narrative, which frames the debate as the outcome of liberal 'political correctness', and argues that these developments have empowered radical sectors who use contemporary values to 'pass judgement' on the past, and thereby denigrate Portuguese history and identity.

The coverage of George Floyd's killing amplified existing contestations in the ongoing Portuguese debates about the legacies of colonization, as anti-racist activists and scholars used media attention on the Black Lives Matter (BLM) movement to advocate for a 'translation' of BLM struggles into the Portuguese context. $\underline{6}$ While condemnation of Floyd's killers was widespread, in tandem with reprobation of Donald Trump's presidency, large sectors in Portuguese society refrained from accepting the existence of similarities between racist (police) violence in the United States and the realities of Portugal. Nonetheless, the strength of the narrative placing Portugal on the map of global racism became evident with the anti-racism demonstrations on 6 June 2020. Previous years and months had been marked by several acts of police violence and hate crimes, which sparked media attention. The kidnap and torture of black young men in the police station of Alfragide (Lisbon metropolitan area) in 2015 triggered some protests (mostly) by anti-racism associations. January and February 2020 witnessed, on different occasions, silent marches and protests in several Portuguese cities in response to the killing of Giovanni Rodrigues, a student from Cape Verde, who had been brutally beaten by a group of Portuguese men in late December 2019; the beating of Cláudia Simões, a black woman, by a police officer following an incident over a bus ticket; and a violent police incursion into the Jamaica neighbourhood, a deprived residential area mostly inhabited by Black population in the Lisbon metropolitan area. In March 2020, Ihor Homenyuka, a Ukrainian man, was tortured to death by officers of the Foreigners and Borders Service at Lisbon airport. The case occurred during the Covid-19 lockdown and triggered no significant outcry or demonstrations. Floyd's murder - which took place precisely when the 
lockdown restrictions were beginning to be lifted in Portugal - fuelled a mobilization that surpassed participation in previous protests: thousands went onto the streets of Lisbon, a thousand in Oporto, hundreds in Coimbra, and smaller numbers in Braga, Viseu, Guarda and Faro. The protests had been called mostly by anti-racist organizations (including collectives combating anti-Roma racism) and activists, though other collectives also joined. For instance, the protests in Oporto brought together a march against labour precarity (which hits racialized sectors particularly hard) and the march against racism. Some politicians, especially from far-left parties, like Black MP Beatriz Dias, joined the rallies. When compared with photos of 'regular' demonstration in Portugal (e.g. Labour Day and Carnation Revolution Day), the photos of the 6 June 2020 protests signal that there was a strong presence of Black population and of young adults (White and Black). ${ }^{7}$ Nurtured by ongoing anti-racist activism (often influenced by US activism) and by post-colonial scholarship on national myths, these demonstrations mark an important moment when local anti-racist struggles succeeded in advancing a public narrative that frames Portuguese racism as part of a global history of racism. The slogans hint precisely at this convergence: alongside symbols and slogans associated with BLM, both in the English original (e.g. 'I can't breathe') and their Portuguese translation, there were slogans in Portuguese pointing directly to the national context: 'Lisbon was built with pepper and slaves, the least you can do is protest'; 'Justice for Cláudia Simões'.

The incident with Viera's statue 4 days later directed media attention to this historical figure and more broadly to the transnational calls to decolonize. Journalists and scholars from different political backgrounds wrote editorials and op-eds on the subject. Some historians argued for a more critical engagement with the legacies of the Priest. $\underline{8}$ There has been, however, resistance (and indifference) towards this anti-colonial narrative among large sectors of Portuguese society. That may partially result from the persistence of myths that memorialize Portuguese colonization as exceptional, namely assumptions that it was foremost a benign form of 'cultural expansion' and a promoter of 'cultural encounters' with 'exotic' ( 'undeveloped') Peoples. This imaginary of the 'Discoveries' has often been juxtaposed with the Spanish conquest of America. The celebration of miscegenation in lusotropicalism ${ }^{2}$ was used specifically to discursively distinguish Portuguese colonialism from segregationist systems like apartheid South Africa and the United States. The fact that precisely Vieira became a key reference in contestations over memory in Portugal simply reinforced the alienation felt by significant sectors of society from the calls to decolonize. After all, Vieira tends to be memorialized in Portuguese popular culture and official discourses (e.g. school curricula) for two positive traits: as a 
talented writer and orator who exposed the hypocrisy and greed of his society, and as the most prominent historical Portuguese figure who was persecuted by the Inquisition because he was suspected of being influenced by Judaism and of having sympathy for the Jews. Indeed, Vieira bravely opposed the persecution of the New Christians $\underline{10}$ and the confiscation of their property by the all mighty Inquisition. Consequently, some proponents of the Priest were quick to suggest that Vieira was 'once again' being persecuted by the Inquisition. $\underline{11}$

The inaccuracy of such comparisons signals how the popularization of critical engagement with Vieira is far from immune to misunderstandings, traps and backlash. However, as some scholars involved in the debate have argued, Vieira's writings and actions make him an extremely pertinent historical figure for a better understanding of Portuguese colonization. $\underline{12}$ Vieira defended the transatlantic slave trade as a necessary system for the economic viability of Brazil as a Portuguese colony. He fiercely condemned enslaved Blacks who escaped captivity and developed autonomous communities such as the famous Quilombo de Palmares. His confrontations with Portuguese settlers in Brazil, where he acted on behalf of the Society of Jesus, $\frac{13}{}$ were part of a larger power struggle involving different colonial forces competing for the appropriation of land from Indigenous populations. His defence of the Indigenous populations was always selective and entangled in forms of (cultural) extermination policies inherent to the system of religious missions. Only the Indigenous who did not resist colonization and converted to Catholicism were to be protected, and only as long as they remained obedient to the Society of Jesus. Vieira's actions and writings reveal above all a faithful servant of the missionary project of the Society of Jesus and a defender of the interests of the Portuguese crown, that is, he emerges as a key historical figure who worked for two fundamentally racist European institutions in their exploitation of colonized Peoples.

Therefore, engaging with Vieira's life encourages a critical discussion of the many dimensions of Portuguese colonial violence and the collusion, in Portuguese history, of the Catholic Church with the transatlantic slave trade, the colonial appropriation of land and the prosecution, killing and mass death of the Indigenous populations in Brazil. $\underline{14}$ In that sense, more and better knowledge of Vieira's life may provide a strong refutation of fairy-tale-like narratives about the 'Discoveries' that persist among large sectors of the Portuguese population. What has been less present in the ongoing debates is how Viera's troubles with the Inquisition could also stimulate a critical discussion of Portuguese anti- 
Semitism. In Portugal, anti-Semitism is understood first and foremost in the context of the Shoah, and the Portuguese Inquisition is often relegated to an unpleasant footnote in Portuguese history, derived from the Vatican's influence on the country, thus positioning the many pogroms of Jews in Portugal to a marginal space in contemporary politics of remembrance. The critical discussion of Vieira and the society he lived in could hence contribute to the dissemination of more knowledge about the important Jewish presence in Portuguese social fabric, and the role played by anti-Semitism and the killing of Jews in the violent construction of Portugal as a Catholic nation.

These ongoing contestations over historical memory, alongside the influence of the BLM movement in anti-racist activism in Portugal, co-exist with two other major developments in the country: first, the eruption of a parliamentary far-right. The CHEGA (meaning 'enough') party, founded in 2019 - running on an anti-establishment, anti-corruption and anti-criminality discourse - had one deputy elected in the 2019 legislative elections and, according to surveys, has been increasing its popularity ever since. Second, predictions of a major economic crisis related to the effects of the Covid-19 pandemic in a country still barely recovering from the European sovereign debt crisis. CHEGA has been intensifying its hate speech against anti-racism activists and politicians, while denying the existence of racism in Portugal and reiterating its pride in the Portuguese police forces and in Portuguese history. The party tries to replicate a strategy used by other far-right parties which succeeded in mobilizing electorates in other parts of the world (e.g. in Brazil, the Philippines, Hungary, France): it describes Portuguese economic problems as a side-effect of corrupt politicians and 'profiteering' minorities, while displacing the focus of political debate onto cultural identitarian issues.

It is too soon to know whether ongoing debates on the legacies of Portuguese colonization will effectively counter the increasing attempts by the far-right to invoke nationalistnativist tropes and the traditional role of Catholicism in Portuguese identity to wage sensationalized media-focused 'cultural wars', and whether, concomitantly, the vitality of recent anti-racism mobilizations and critical engagement with colonial myths will succeed in deconstructing inegalitarian structures of power and contribute to renewed investment in democracy, social justice and social emancipation.

\section{Notes}

1. The words Descobrimentos and Descobertas have been traditionally used by Portuguese historiography to refer to the exploration of maritime sea routes, the conquest 
and the colonization of territories in Africa, the Americas and Asia by Portuguese sailors and armed forces in the 15th and 16th centuries. This period was marked by the beginning of the Transatlantic slave trade. Critical voices contest not only the celebration of this period in Portuguese politics of memory, but also the concept itself as a euphemism for colonization.

2. The Portuguese Colonial War (1961-1974) was fought in Angola, Mozambique, and Guinea-Bissau, where it is remembered as the War of Liberation. The 1974 Carnation Revolution in Portugal paved the way for cease-fire agreements with the African liberation movements. Mozambique, Cape Verde, São Tomé and Príncipe, and Angola became independent in 1975. Guinea-Bissau had unilaterally declared independence on 31 September 1973.

3. The inscription refers to Indigenous Peoples of Brazil. In 1614, António Vieira accompanied his parents to the Portuguese colony of Brazil, where he spent a significant part of his life. As a Jesuit priest, he was an important historical figure in the evangelization of the Indigenous.

4. The words 'Indigenous Brazilian children' are not accurate for the period, when Portuguese occupied only parts of what would be later Brazil. Therefore, I used the concept that is common in contemporary Portuguese historiography when referring to that period.

5. Xavier (2020).

6. See, for instance, Roldão (2020).

7. See Esquerda (2020).

8. See, for instance, Cardim (2020).

9. The word luso refers to a pre-Roman People which some Portuguese nationalist historiography memorializes as the ancient Portuguese. The concept lusotropicalism refers to a theory developed by the Brazilian Gilberto Freyre (1900-1987). Freyre argued that Portuguese colonialism was distinctive, because the Portuguese, as a product of racial and cultural hybridism due to their historical contacts with Muslims and Jews, were culturally more equipped to adapt to the tropics and mix with other cultures and races. Freyre, who did not articulate the pervasiveness of rape and sexual exploitation of colonized women in Portuguese colonies, claimed that Portuguese colonialism was more humane, less violent and prone to miscegenation. Lusotropicalism was enthusiastically embraced and disseminated by the Portuguese State propaganda, specifically in the postWorld War II period to refute increasing international pressures to decolonize. 
10. In 1496, the Portuguese King decreed that all Jews had to convert or leave the country. Converted Jews and their descendants were known as 'New Christians'. The fierce antisemitic persecutions of the following centuries targeted New Christians, who were accused of practicing Judaism secretly. See the 1506 Lisbon pogrom and the actions of the Portuguese Inquisition (established in 1536). On the history of Portuguese Inquisition, see, for instance, Bethencourt (2009).

11. See, for instance, Ferreira (2020).

12. Cardim (2020). Cardim authored important scientific work about Vieira and about Indigenous resistance to Portuguese colonization. See, for instance, Cardim (2019); Cardim and Sabatini (2011).

13. The Catholic religious order Compañía de Jesus (Society of Jesus), also known as Jesuit Order, was founded in 1540 by Ignatius of Layola from Navarre (modern Spain) and six companions from Navarre, Castille (modern Spain), Savoy (modern France and Italy) and Portugal. The first Governor General of Brazil brought the first Jesuits to the colony in 1549 to Christianize the Indigenous Peoples. The Jesuits played a key role in the colonization of Brazil, namely in education and through the establishment of Jesuit missions where the Indigenous worked for the Society. The Jesuits' power and control of significant parts of the land led to violent disputes with the settlers. In 1759, the Jesuits were formally expelled from the Portuguese empire and their properties were confiscated. 14. Certainly, while the settlers aimed at the expulsion and the mass killing of Indigenous Peoples, the Catholic Church strived for their evangelization. However, in reality that meant widespread killings, tortures, extirpation of religious-cultural practices and introduction of logistics which caused mass death. For example, the spread of diseases brought from Europe in the missions costed huge casualties among the Amerindian.

\section{References}

Bethencourt, F (2009) The Inquisition. A Global History, 1478-1834. Cambridge: Cambridge University Press.

Cardim, P (2019) Os povos indígenas, a dominação colonial e as instâncias de justiça na América Portuguesa e Espanhola. In: Domingues, Â, Resende, MLCD, Cardim, P (eds) Os indígenas e as justiças no mundo ibero-americano (sécs.XVI-XIX). Lisboa: Atlantica. Lisbon Historical Studies, Centro de História da Universidade de Lisboa / CHAM / Programa de Pós-Graduação em História / Universidade Federal de São João del-Rei, pp. 29-84. 
Cardim, P (2020) Para uma visão mais informada e plural do Padre António Vieira. Expresso, 25 June. Available at: https://expresso.pt/opiniao/2020-06-25-Parauma-visao-mais-informada-e-plural-do-padre-Antonio-Vieira.

Cardim, P, Sabatini, G (eds) (2011) António Vieira, Roma e o universalismo das monarquias portuguesa e espanhola. Lisboa: CHAM.

Esquerda (2020) Uma multidão anti-racista nas ruas de Portugal. esquerda.net, 6 June. Available at: https://www.esquerda.net/artigo/uma-multidao-anti-racista-nas-ruasde-portugal $/ 68426$.

Ferreira, PF (2020) Alice Vieira: 'É ignorância. Não sabem quem foi o Padre António Vieira'. Diário de Notícias, 12 June. Available at: https://www.dn.pt/pais/alicevieira-isto-e-ignorancia-nao-sabem-quem-foi-o-padre-antonio-vieira-12304485.html.

Roldão, C (2020) De Ferguson à Palestina e Amadora: o abolicionismo de Ângela Davis. Público, 19 June. Available at: https://www.publico.pt/2020/06/19/culturaipsilon/critica/ferguson-palestina-amadoraabolicionismo-angela-davis-1920889.

Xavier, ÂB (2020) A ironia intrínseca à estátua do Padre António Vieira. Ípsilon, 25 June. Available at: https://www.publico.pt/2020/06/25/culturaipsilon/opiniao/ironiaintrinseca-estatua-padre-antonio-vieira-1921786. 